\title{
What are you Feeding your kids?
}

\author{
Tamara Daniela Frydman, Jesus Manuel De Aldecoa and Melchor Alpizar* \\ Centro Especializado en Diabetes, Mexico \\ *Corresponding author: Melchor Alpizar, Centro Especializado en Diabetes, Obesidad y Prevención de Enfermedades \\ Cardiovasculares, S.C. Mexico City
}

\begin{tabular}{|c|c|}
\hline ARTICLE INFO & \\
\hline Received: 崖 July 02, 2019 & Citation: Frydman TD, De Aldecoa JM, Alpizar M. What are you Feeding your kids?. \\
\hline Published: 㬎 July 12, 2019 & Biomed J Sci \& Tech Res 19(4)-2019. BJSTR. MS.ID.003329. \\
\hline
\end{tabular}

\section{Introduction}

Obesity is defined in general terms as a chronic illness characterized by an excess of body fat that arises mainly from the intake and use of caloric energy imbalance. When this state is present since childhood, the body develops an inflammatory permanent state that sets the stage for the development of chronic illness such as diabetes and hypertension, leading up to cardiac dysfunction in most cases. The permanent inflammatory state comes from chronic adipocyte dysfunction characterized by 3 main features: Site (visceral fat accumulation that leads to organ damage), Size (hypertrophic adipocytes that absorb more fat) and Cyte (referring to the cytokines and immunological cells such as macrophages that respond to and prolong the inflammation) [1]. On this note, several authors have agreed on the fact that most adipocytes that a human has in their lifetime develop before puberty and after that, these cells can grow in size and not in number so these fist years of life have the power to determine a lifetime of battle against obesity if hypertrophy of adipocytes is the give state [2].

Mexico in this area has a leading role, with a prevalence for obesity at 12 years of age of approximately 33\%. This number though has to be considered to be under the real amount given that most of these cases are detected through measurement of Body Mass Index (BMI) and this is not the most trustworthy of indicators when one realizes that many children can have a normal BMI despite the fact that they have a body composition that is mostly fat and very little muscle [3]. When we see these numbers in children, the most important question that comes to mind is why? It is extremely important to determine the causes for this health issue in order to prevent more chronic diseases in adulthood. Studies have shown that eating patterns that one develops in childhood have a tendency to prosper during growth as well as exercise routine behavior. By analyzing these variables it's easier to understand Mexican prevalence numbers being that this country has the number one consumer place for sodas and sweetened flavored water. Also, Mexican diet is most prominently based on corn and wheat consumption and it is also being influenced more every day by occidental diet customs that encourage fast food and industrialized product intake [1].

In Mexico it is customary for children not to have breakfast as soon as they wake up in part due to the early work schedule that parents have in order to support their families. Consequently, kids generally eat breakfast in school during recess hours and therefore experience long fasting hours which forces the organism to succumb to alternative metabolic pathways to obtain the energy that the body needs. It is known that the nervous central system requires up to $60 \%$ of the body's necessary glucose and these percentages can increase in these cases due to the fact that children during these fasting hours are in class and are required to concentrate. Glucogenolysis is a metabolic pathway that provides the organism with glucose in those cases where it is not obtained exogenously, after that the next route is called gluconeogenesis which primarily uses amino acids from muscle to normalize glycemic levels. This explains the energetic homeostasis that doesn't correct the hunger that the child feels in this moment given that the stomach remains empty. Ultimately, when this child eats with hunger, the amount of food increases, promoting a hyperglycemic state that ends in de novo lipogenesis [2]. This cycle in Mexican children explains the high levels of body fat leading towards childhood obesity in most cases. Action in this regard is urgently needed to fight this problem that is most prevalent in Mexico. 


\section{References}

1. Pérez Herrera A, Cruz López M (2019) Situación actual de la obesidad infantil en México. Nutricion Hospitalaria 36(2).

2. Choe SS, Huh JY, Hwang IJ, Kim JI, Kim JB, et al. (2016) Adipose tissue remodeling: its role in energy metabolism and metabolic disorders. Frontiers in endocrinology $7(30)$.

\section{ISSN: 2574-1241}

DOI: 10.26717/BJSTR.2019.19.003329

Melchor Alpizar. Biomed J Sci \& Tech Res

(C) $(1)$ This work is licensed under Creative

Submission Link: https://biomedres.us/submit-manuscript.php
3. Alpizar M, Peschard VG, Escalante Araiza F, Altamirano Bustamante N, Murata C, et al. (2017) Smoothed body composition percentiles curves for Mexican children aged 6 to 12 years. Children 4(12): 112

$\begin{array}{ll}\text { BIOMEDICAL } & \text { Assets of Publishing with us } \\ \text { RESEARCHES } & \text { - Global archiving of articles } \\ & \text { - Immediate, unrestricted online access } \\ & \text { - Rigorous Peer Review Process } \\ & \text { - Authors Retain Copyrights }\end{array}$

